\title{
Induction of complete courtship ritual in Amblyomma cajennense using 2,6-dichlorophenol at female-equivalent quantities
}

\author{
Indução dos comportamentos de cortejo em Amblyomma cajennense pelo 2,6-diclorofenol
} em quantidades equivalentes às das fêmeas

\author{
Kennedy Kiriira Gachoka ${ }^{1}$; Lorena Lopes Ferreira ${ }^{1}$; Carla Cristina Braz Louly ${ }^{1}$; Lígia Miranda Ferreira Borges ${ }^{2 *}$ \\ ${ }^{1}$ Escola de Veterinária, Universidade Federal de Goiás - UFG \\ ${ }^{2}$ Instituto de Patologia Tropical e Saúde Pública, Universidade Federal de Goiás - UFG
}

Received March 18, 2011

Accepted May 10, 2011

\begin{abstract}
In order to clarify the role of 2,6-dichlorophenol (2,6-DCP) in the courtship of Amblyomma cajennense, sexually mature males that had previously fed on rabbits were tested in bioassays. The males were released onto dummies treated with whole female extract or synthetic 2,6-DCP at a concentration of two female equivalents, or with hexane (control), and their responses were observed. In the presence of both the extract and 2,6-DCP, excitation was observed among the males, expressed in the form of touching and probing the dummy, and mounting occurred readily. The percentages of mounting $(73 \%)$ and tipping over $(60 \%)$ were equal in the two treatments and higher than in the control group (27 and 20\%, respectively). Relatively short durations of mounting were recorded, and these were statistically similar in all treatments. Almost all instances of mounting resulted in tipping-over behavior. A few isolated cases of males that went directly to ventral positioning without mounting were observed. It was confirmed that 2,6-DCP alone is capable of mediation of mounting behavior in A. cajennense.
\end{abstract}

Keywords: 2,6-DCP, Amblyomma cajennense, mount, sex pheromone, tick.

\section{Resumo}

Visando elucidar o papel do 2,6-diclorofenol (2,6-DCF) no cortejo de Amblyomma cajennense, machos sexualmente maduros, previamente alimentados em coelhos, foram avaliados em testes biológicos. Os machos foram liberados sobre manequins tratados com um extrato de fêmeas, ou com 2,6-DCF sintético na concentraçáo equivalente a duas fêmeas, ou com hexano (controle), e suas respostas foram observadas. Na presença do extrato e do 2,6-DCF, a excitação dos machos foi expressa na forma de toques e sondagens, e a monta ocorreu rapidamente. As porcentagens de respostas observadas nos dois tratamentos foram iguais, sendo a monta $(73 \%)$ e retorno na superfície ventral (60\%) mais altos que no controle ( 27 e $20 \%$, respectivamente). Foram observados períodos de monta relativamente curtos, sendo esses estatisticamente iguais em todos os tratamentos, e quase todos resultando em posicionamento ventral. Alguns casos isolados de posicionamento ventral sem monta foram observados. Foi confirmado que o 2,6-DCP sozinho é capaz de mediar o comportamento de monta de $A$. cajennense.

Palavras-chave: 2,6-DCF, Amblyomma cajennense, monta, feromônio sexual, carrapato.

Amblyomma cajennense (Acari: Ixodidae) is a tick of great importance in relation to public health in South America, principally because of its capacity to transmit the causative agent of Brazilian spotted fever, Rickettsia rickettsii, to humans and animals (SUCEN, 2004; SANGIONI et al., 2005). The female sex

${ }^{*}$ Corresponding author: Ligia Miranda Ferreira Borges Instituto de Patologia Tropical e Saúde Pública,

Universidade Federal de Goiás - UFG, Rua 235, s/n,

Setor Universitário, CEP 74605-050, Goiânia, GO, Brazil

e-mail: ligia@iptsp.ufg.br attractant pheromone consists of 2,6-dichlorophenol (2,6-DCP), which is a highly volatile substance. This phenol has so far been reported from 18 species of Ixodidae in seven genera, and it has great potential for exploitation with the aim of controlling these species (SONENSHINE, 2006). However, the behavioral and chemical studies that are necessary for validating the role of 2,6$\mathrm{DCP}$ as a sex attractant pheromone have only been conclusive in eight of these species (SONENSHINE et al., 1976; KELLUM; BERGER, 1977; SILVERSTEIN et al., 1983; BORGES et al., 2002; 
LOULY et al., 2008). In two of these, it has been further associated with induction of mounting behavior (BORGES; RIBEIRO, 1999; BORGES et al., 2002; LOULY et al., 2008). On the other hand, in certain species, 2,6-DCP together with cholesteryl esters are necessary for the males to recognize and mount on sexual partners (HAMILTON; SONENSHINE, 1988; SOBBHY et al., 1994), and thus the latter components collectively constitute another category: mounting sex pheromone.

2,6-DCP in $A$. cajennense was identified and characterized for male courtship behavior using live females and impregnated rubber septa, which served as odor sources in an arena olfactometer (LOULY et al., 2008). However, subsequent quantification of 2,6-DCP in $A$. cajennense yielded a mean value of $2.15 \mathrm{ng} \cdot \mathrm{mL}^{-1}$ per female (GACHOKA et al., 2010), which was far less than the 50 to $5000 \mathrm{ng}$ that had been tested above by Louly et al. (2008). Therefore, the aim of the present study was to determine the behavioral responses that 2,6-DCP provokes in $A$. cajennense courtship at quantities close to what is perceived by the males under natural conditions.

Fully engorged $A$. cajennense females were collected from naturally infested horses and were maintained in incubators ( $\mathrm{T}=27^{\circ} \mathrm{C}, \mathrm{RH}>80 \%$ ) in the laboratory in order to establish a colony, in accordance with the method described by Sanavria; Prata (1996). For this purpose, successive life cycle stages were allowed to feed on the backs of rabbits (Oryctolagus cuniculus). To obtain the pheromone, females that had fed for six days were placed in hexane in sealable glass tubes, followed by sonication for 15 minutes. The filtrate was then concentrated under nitrogen gas, as described in the method used by Borges et al. (2002). In total, about 1,500 females in different batches were used for extraction of the sex pheromone.

The bioassays to evaluate the role of 2,6-DCP as a mounting pheromone were done in an isolated odor-free test room, under controlled conditions of temperature and relative humidity ( $\mathrm{T}=25^{\circ} \mathrm{C}, \mathrm{RH}>50 \%$ ). The method described by Borges; Ribeiro (1999) was used, with modifications. A Petri dish $(70 \mathrm{~mm}$ in diameter and $10 \mathrm{~mm}$ in depth) placed over a glass-covered water bath $\left(37^{\circ} \mathrm{C}\right)$ served as the test arena. The heated water bath served to simulate the body of a host. Smooth, inert, solid spherical glass beads of approximately the same size as feeding female ticks (dummies of diameter $5 \mathrm{~mm}$, height $4 \mathrm{~mm}$ and weight $0.1 \mathrm{~g}$ ) were roughened on their surface with sandpaper to reduce slipperiness and were abraded flat on one side with a file to prevent them from rolling over. Two female-equivalents of the pheromone extract $(20 \mu \mathrm{l})$ or $4.30 \mathrm{ng}$ of the synthetic 2,6-DCP (which is approximately the quantity produced by two females), of analytical-reagent grade, purchased from Sigma (St. Louis, MO, USA), was placed on each glass dummy. The dummies were left for 5 seconds in a fume chamber to allow for complete solvent evaporation. This was then placed in the middle of the Petri dish arena for the bioassay. The control dummies were treated in the same way, and only hexane was added. Each male was tested against a newly treated unused dummy.

Fifteen freshly detached sexually mature males (after five days of feeding) were released individually next to a dummy in each treatment (45 males in total) using a pair of forceps, and the Petri dish was then covered. Using a camera, the data gathered included: 1) number of males that mounted; 2) number that tipped over beneath the dummy (ventrolateral positioning); 3) lengths of time spent in the mounted and tipped-over positions; and 4) associated behavior. Those that failed to mount after 60 seconds were reintroduced up to three times before scoring the response. Mounting referred to a position in which all the legs were entirely in contact with the bead, while tipping over was defined as a position in which it was possible to partly observe the posterior ventrolateral side of the probing male from above, with a degree of arrestment. One-month-old adults were used in the bioassay. The mounting responses were analyzed using the chi-square test, while time duration analyses were done using one-way ANOVA at a $95 \%$ confidence level.

In the presence of either the extract or the synthetic 2,6-DCP, some of the males were observed to attempt to push themselves in between the bead and the surface on which it sat, such that it was sometimes moved but did not roll over. Others engaged in sideways movements in a crawled-over position against the dummy. In the control experiment, most of the males did not mount the dummy, while those that did dismounted and then walked across to the side and to the underside of the cover of the Petri dish and back to the floor again. Slowed activity occurred once the males had successfully oriented themselves and located the pheromone source. Because of the flattened bottom of the dummy that had been created for stability purposes in this bioassay, the males could only attain ventrolateral positioning after tipping over, rather than the complete ventral positioning attained with live females in nature.

Overall, it was observed that statistically significant induction of mounting activity and tipping over was caused both by the extracts from fed females and by the synthetic 2,6-DCP, in comparison with the control. In fact, there was a great tendency among the males to seek out and mount the dummy upon the first release. The results showed that $73.33 \%$ of the males attained the mounted position in the tests using the extract and synthetic 2,6-DCP, compared with $26.67 \%$ in the control (Table 1). These percentages are very close to the 67 and $73 \%$ reported by Louly et al. (2008) in experiments using rubber septa treated with $500 \mathrm{ng}$ of 2,6-DCP and live fed females, respectively. However, those authors reported discrepancies such that 50 and $5000 \mathrm{ng}$ in the same series failed to induce mounting at all. Nevertheless, the attractiveness of 2,6-DCP to $A$. cajennense was proven at each of the concentrations used by those authors, determined as a measurement of frequency of displacement angles of between 0 and $10^{\circ}$ observed over a distance of $5 \mathrm{~cm}$ from the odor source upwind.

Although our bioassay had slightly different objectives from those of Louly et al. (2008), our technique provided an immense improvement in the sense that, unlike rubber septa, glass dummies are not porous to the pheromone placed on them, thus ensuring that the quantities perceived by the tick are those desired. This, coupled with the consistent results reported previously from quantification of pheromone amounts released naturally using two different methods (GACHOKA et al., 2010), indicates that the tick behavior reported here is accurate and dependable as a premise upon which further studies can be carried out.

The instances of mounting and tipping over were in some manner concomitant, in that almost all the males that attained the 
Table 1. Percentage and mean duration of mounting and tipping over of Amblyomma cajennense males on glass dummies treated with two female-equivalents of the female pheromone extract or $4.30 \mathrm{ng}$ of synthetic 2,6-DCP (approximately the quantity produced by two females), or with hexane as a control.

\begin{tabular}{lccc}
\hline Treatment & \% mounted & Time (s) [mean $\pm s d.]^{1}$ & \% tipped over \\
\hline Extract & $73.33^{\mathrm{a}}$ & $6.82 \pm 2.46^{\mathrm{a}}$ & $60^{\mathrm{a}}$ \\
$2,6-\mathrm{DCP}$ & $73.33^{\mathrm{a}}$ & $4.91 \pm 1.23^{\mathrm{a}}$ & $60^{\mathrm{a}}$ \\
Control & $26.67^{\mathrm{b}}$ & $3.13 \pm 0.52^{\mathrm{a}}$ & $20^{\mathrm{b}}$ \\
\hline
\end{tabular}

Means within a column followed by the same letter are not significantly different $(P>0.05)$. ${ }^{1}$ Data on times was log-transformed before ANOVA.

mounted position on the dorsal surface proceeded to tipping over. The percentage that did this in the extract and synthetic 2,6-DCP groups was $60 \%$, compared with $20 \%$ in the control (Table 1). Equal degrees of activity were recorded with the extract and the synthetic 2,6-DCP, while it was less in the controls.

Relatively short durations of mounting were recorded. They were statistically similar in all treatments, and almost all instances of mounting resulted in tipping-over behavior (Table 1). In these experiments, slight qualitative differences between $A$. cajennense and other reported species were observed. For instance, $A$. cajennense had relatively short but numerous contact times, thus appearing to give up rather quickly and move on. While Borges and Ribeiro (1999) reported average durations of 60 seconds in this phase, in experiments using the tropical horse tick Dermacentor nitens, A. cajennense showed much lower averages. The differences in time durations between species may be attributable to mechanical and structural features that are outside of the scope of this study. Such features would be associated with each tick species and would not be found on dummies.

According to Hamilton and Sonenshine (1988) and Sobbhy et al. (1994), males attracted to 2,6-DCP placed on inanimate objects leave immediately when they fail to recognize these objects as potential mates, even if they make physical contact with them. In such cases cholesteryl esters, collectively referred to as mounting sex pheromone, are considered necessary for the males to recognize the objects as sexual partners. In Rhipicephalus sanguineus and Rhipicephalus (B.) microplus, these processes are not mediated by the phenol (LOULY et al., 2008; BRUYNE; GUERIN, 1998). The first report of 2,6-DCP as an attractant and mounting sex pheromone was made by Borges et al. (2002), in relation to the tropical horse tick D. nitens. In this, 2,6-DCP was shown to stimulate the complete courtship response sequence of orientation, location, mounting and ventral positioning. The most peculiar observation in the present study was the instances in which a male went straight to ventrolateral positioning without necessarily mounting. Although only observed in very few individuals, this is the first report of such a phenomenon and seems to contradict the stepwise approach currently widely accepted as standard in tick courtship. It would be interesting to investigate whether this anomaly occurs frequently with $A$. cajennense in nature.

On the basis of this study, it is reasonable to conclude that A. cajennense joins the emerging list of species for which 2,6-DCP has been validated not only as a sex attraction pheromone but also as a mounting pheromone, based on tests using quantities equal to those emitted naturally. Several studies have successfully demonstrated the potential for using 2,6-DCP in tick control, either by killing those attracted to pheromone-acaricide incorporated decoys or by disruption of their reproduction behavior/sequence (ZIV et al., 1981; SONENSHINE et al., 1992; BORGES et al., 2007). Based on the latter study reports and on our conclusion above, similar studies to evaluate the potential utility of 2,6-DCP for $A$. cajennense control are recommended as further investigations.

\section{Acknowledgements}

The authors are indebted to CNPq-TWAS for financial support in the form of a grant fellowship to Kennedy K. Gachoka.

\section{References}

BORGES, L. M. F; RIBEIRO, M. F. B. Presence of sex pheromones in Anocentor nitens (Acari: Ixodidae). Journal of Medical Entomology, v. 36, n. 1, p. 50-54, 1999.

BORGES, L. M. F. et al. The role of 2,6-dichlorophenol as sex pheromone of the tropical horse tick Anocentor nitens (Acari: Ixodidae). Experimental and Applied Acarology, v. 27, p. 223-230, 2002. http://dx.doi.org/10.1023/A:1021620215416

BORGES, L. M. F. et al. Efficacy of 2,6-dichlorophenol lure to control Dermacentor nitens. Veterinary Parasitology, v. 147, n. 1-2, p.155-160, 2007. PMid:17459588. http://dx.doi.org/10.1016/j. vetpar.2007.02.037

BRUYNE, M.; GUERIN, P. M. Contact chemostimuli in the mating behaviour of the cattle tick, Boophilus microplus. Archives of Insect Biochemistry and Physiology, v. 39, n. 2, p. 65-80, 1998. http://dx.doi.org/10.1002/(SICI) 1520-6327(1998)39:2\%3C65::AIDARCH3\%3E3.0.CO;2-W

GACHOKA, K. K. et al. Comparison of two methods to quantify 2,6-dichlorophenol from tick Amblyomma cajennense by GC/MS-SIM. Journal of the Brazilian Chemical Society, v. 21, n. 9, p. 1642-1647, 2010. http://dx.doi.org/10.1590/S010350532010000900007

HAMILTON, J. G. C.; SONENSHINE, D. E. Evidence for occurrence of mounting sex pheromone on body surface of female Dermacentor variabilis (Say) (Acari: Ixodidae). Journal of Chemical Ecology, v. 14, n. 1, p. 401-410, 1988. http://dx.doi.org/10.1007/BF01022555

KELLUM, D.; BERGER, R. S. Relationship of the occurrence and function of 2,6-dichlorophenol in two species of Amblyomma (Acari: Ixodidae). Journal of Medical Entomology, v. 13, n. 6, p. 701-705, 1977.

LOULY, C. C. B. et al. More about the role of 2,6-dichlorophenol in tick courtship: identification and olfactometer bioassay in Amblyomma cajennense and Rhipicephalus sanguineus. Memórias do Insituto Oswaldo Cruz, v. 103, n. 1, p. 60-65, 2008. http://dx.doi.org/10.1590/S007402762008000100009

SANAVRIA, A.; PRATA, M. C. A. Metodologia para colonização do Amblyomma cajennense (Fabricius, 1787) (Acari: Ixodidae) em laboratório. Revista Brasileira de Parasitologia Veterinária, v. 5, n. 2, p. 87-90, 1996. 
SANGIONI, L. A. et al. Rickettsial infection in animals and Brazilian spotted fever endemicity. Emergence of Infectious Diseases, v. 11, n. 2, p. 265-270, 2005. PMid:15752445.

SÃO PAULO (Estado). Secretaria de Estado da Saúde. Superintendência de Controle de Endemias - SUCEN. Manual de Vigilância Acarológica. Coordenado por Vera Lúcia Fonseca de Camargo-Neves. São Paulo, 2004.

SILVERSTEIN, R. et al. Occurrence of 2,6- dichlorophenol in the hard ticks, Hyalomma dromedarii and Hyalomma anatolicum excavatum and its role in mating. Journal of Chemical Ecology, v. 9, n. 12, p. 1543-49, 1983. http://dx.doi.org/10.1007/BF00988420

SOBBHY, H. et al. Cholesteryl esters on the body surfaces of the camel tick, Hyalomma dromedarii (Koch, 1844) and the brown dog tick, Rhipicephalus sanguineus (Latreille, 1806). Experimental and Applied Acarology, v. 18, n. 5, p. 265-280, 1994. http://dx.doi.org/10.1007/ BF00132316
SONENSHINE, D. E. et al. 2,6-Dichlorophenol, the sex pheromone of the rocky mountain wood tick, Dermacentor andersoni Stiles and the American dog tick, Dermacentor variabilis (Say). Journal of Chemical Ecology, v. 2, n. 2, p. 201-209, 1976. http://dx.doi.org/10.1007/ BF00987743

SONENSHINE, D. E.; HAMILTON, J.; LUSBY, W. R. The use of cholesteryl esters as mounting sex pheromones in combination with 2,6-dichlorophenol and pesticides to control ticks. US n. 5149526, 1992

SONENSHINE, D. E. Tick pheromones and their use in tick control. Annual Review of Entomology, v. 51, p. 557-80, 2006. PMid:16332223. http://dx.doi.org/10.1146/annurev.ento.51.110104.151150

ZIV, M. et al. Use of sex pheromone, 2,6-dichlorophenol, to disrupt mating by American dog tick, Dermacentor variabilis (Say). Journal of Chemical Ecology, v. 7, n. 5, p. 829-840, 1981. http://dx.doi. org/10.1007/BF00992381 